\section{Rediscovery of an endemic plant Caralluma diffusa (Wight) N.E. Br. (Asclepiadaceae) from Coimbatore District, Tamil Nadu, India, after 160 years}

\author{
V.S. Ramachandran ${ }^{1}$, Binu Thomas ${ }^{2}$, C. Sofiya ${ }^{3}$ \\ \& R. Sasi ${ }^{4}$ \\ 1,2,3,4 Taxonomy and Floristic Laboratory, Department of Botany, \\ Bharathiar University, Coimbatore, Tamil Nadu 641046, India \\ Email: ${ }^{1}$ vsrbotany@gmail.com (corresponding author), \\ 2 binuthomasct@gmail.com, ${ }^{3}$ sofiya.chinnathambi@gmail.com, \\ ${ }^{4}$ sasibotany@gmail.com
}

The genus Caralluma R.Br. of the Asclepiadaceae family is of interest to botanists and succulent lovers alike. Gandhi (1999) brought to light the inadequacy of information and the need for a critical look at the Indian Caralluma. There are 110 species of Caralluma occurring in southern and eastern Africa, extending to the north into the Mediterranean and to the east through Arabia and India (Willis 1973). In India, the genus is represented by 13 species and five varieties (Jagtap \& Singh 1999). Caralluma diffusa (Wight) N.E.Br. was first collected by Robert Wight, and named by him as Boucerosia diffusa, from Coimbatore in 1850 . Henry et al. (1978) listed 224 species of rare and threatened

Date of publication (online): 26 March 2011

Date of publication (print): 26 March 2011

ISSN 0974-7907 (online) | 0974-7893 (print)

Editor: N.P. Balakrishnan

Manuscript details:

Ms \# 02459

Received 13 May 2010

Final received 02 February 2011

Finally accepted 07 February 2011

Citation: Ramachandran, V.S., B. Thomas, C. Sofiya \& R. Sasi (2011) Rediscovery of an endemic species, Caralluma diffusa (Wight) N.E. Br. (Asclepiadaceae) from Coimbatore District, Tamil Nadu, India, after 160 years. Journal of Threatened Taxa 3(3): 1622-1623.

Copyright: (c) V.S. Ramachandran, Binu Thomas, C.Sofiya \& R. Sasi 2011. Creative Commons Attribution 3.0 Unported License. JoTT allows unrestricted use of this article in any medium for non-profit purposes, reproduction and distribution by providing adequate credit to the authors and the source of publication.

Acknowledgements: Thanks are due to Prof. Dr. S. Manian, Head, Department of Botany, Bharathiar University, Coimbatore, for facilities and encouragement. We extend our sincere thanks to Dr. G.V.S. Murthy, Joint-Director, Botanical Survey of India, Southern Circle, Coimbatore, for providing facilities to the literature collections.

OPEN ACCESS | FREE DOWNLOAD

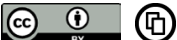

flowering plants from southern India. They stated that "No specimens of Caralluma diffusa

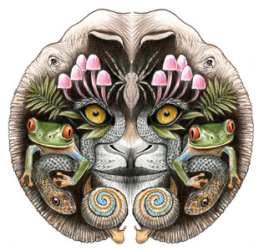
had been deposited in MH". It is one of the endemic species occurring in Coimbatore District. Gamble (1923) gave the distribution of this species as Deccan, arid rocky hills near Coimbatore at an elevation of about $600 \mathrm{~m}$. Srinivasan (1987) also indicated in Flora of Tamil Nadu that its distribution is only from Coimbatore District in Tamil Nadu and the threat status mentioned as rare and threatened. Chithra \& Nair (1999) include 11 species of various genera in the family Asclepiadaceae and among which Caralluma diffusa (Wight) N.E.Br. and Caralluma nilagiriana Kumari \& Subba Rao are considered as endemic to Tamil Nadu. Rao et al. (2003) have also included this species under 'indeterminate status'.

However, while working on the chasmophytic flora of Coimbatore District, we collected this species from Madukkarai Hills of Western Ghats. This plant is usually seen in rock crevices. The local people use the sap of young stems to treat obesity. This note will facilitate the identification of the plants in the wild (Image 1). This species is now under heavy biotic pressure and it is doubtful whether the existing population will continue to survive in those localities. This wild plant is well suited for rock gardens and it can be conserved through ex situ cultivation. The endemism is prone to changes when more and more botanical explorations are undertaken and additional knowledge on the distribution of species are gathered at regional level.

This species is unique for its diffuse branches, very stout and attractive flowers in dense umbels (Hooker 1883). The species of this genus are generally pollinated by small scadophagous, dipterons and perhaps also by beetles (Stevens 1976).

\section{Caralluma diffusa (Wight) N.E. Br.}

in Gard. Chron. 2: 369. 1892; Gamble, Fl. Pres. Madras 2: 862. 1923; Srinivasan in Henry et al., Fl. Tamil Nadu 2: 81. 1987; Jagtap \& Singh, Fasc. Fl. India 24: 201. 1999. Boucerosia diffusa Wight, Ic. Pl. Ind. Or. t. 1599. 1850; Hook.f. Fl. Brit. India 4: 78. 1883.

Specimen examined: 20.vi.2008, Madukkarai Hills, Coimbatore District, Tamil Nadu, coll. Binu Thomas, 3081 Bharathiar University, Department of Botany Herbarium (BUH) (Fig. 1). 


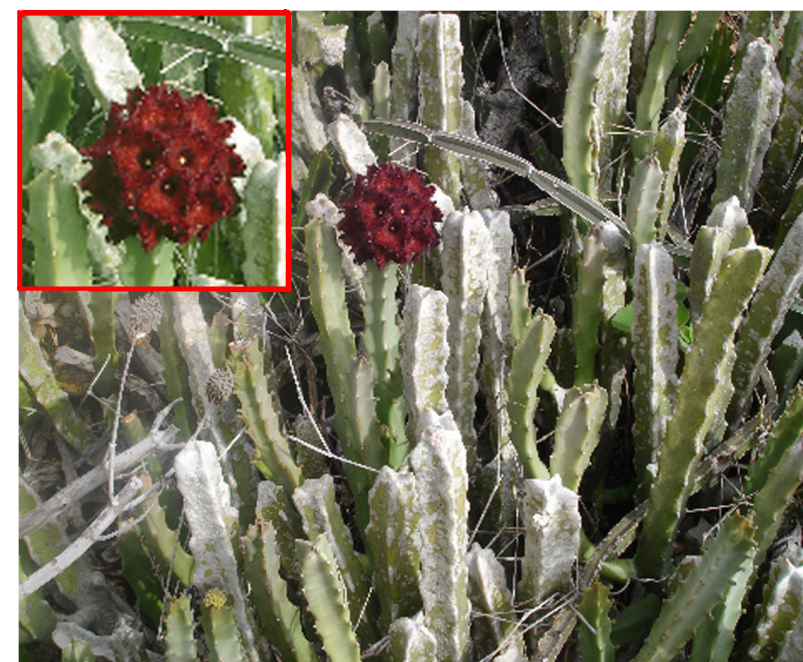

Image 1. Caralluma diffusa (Wight) N.E. Br.

Type: India: Madras Presidency; Coimbatore District, arid rocky mountains near Coimbatore at $600 \mathrm{~m}$ elevation.

Stem fleshy; branches ascending, 4-angled, nearly of equal thickness throughout the branches; internodes 6-12 mm long, 5-15 mm thick, glabrous. Leaves absent, leaf scars present, with appendage-like growth at nodes on angled portion. Flowers in terminal umbellate cymes, many-flowered; bracts ca. $1.5 \times 0.5 \mathrm{~mm}$, triangular, acute at apex, glabrous; pedicels terete, 5-6 mm long, 1-1.5 $\mathrm{mm}$ thick, glabrous. Calyx 5-lobed, divided up to base; lobes ca $3 \times 1 \mathrm{~mm}$, lanceolate, acute at apex, glabrous. Corolla campanulate, ca. $8 \mathrm{~mm}$ long; tube ca. $5 \mathrm{~mm}$ long; lobes 5 , ca. $3 \times 2 \mathrm{~mm}$, ovate, acute at apex, ciliate at margin only, otherwise glabrous. Corona biseriate; the outer annular, arising from base of stamens, closely intact; lobes 5 , ca. $2.5 \times 1.5 \mathrm{~mm}$, with two horn like appendages widely separated from each other; the inner variable, ca. $1 \mathrm{~mm}$ long, linear, arising from inner side of outer corona, overlapping anther-lobes. Stamens 5, ca. $2.5 \mathrm{~mm}$ long; pollinia 5 , pollen masses solitary in each anther cell, yellow, waxy with pellucid layer attached by light brown caudicles. Gynostegium ca. $1.5 \mathrm{~mm}$ long.

Flowering \& Fruiting: April-September.

Distribution: Endemic to Coimbatore, Tamil Nadu.

\section{REFERENCES}

Chithra, V. \& V.J. Nair (1999). Floristic Diversity and Conservation Strategies in India. In the Context of States and Union territories. Botanical Survey of India, Ministry of

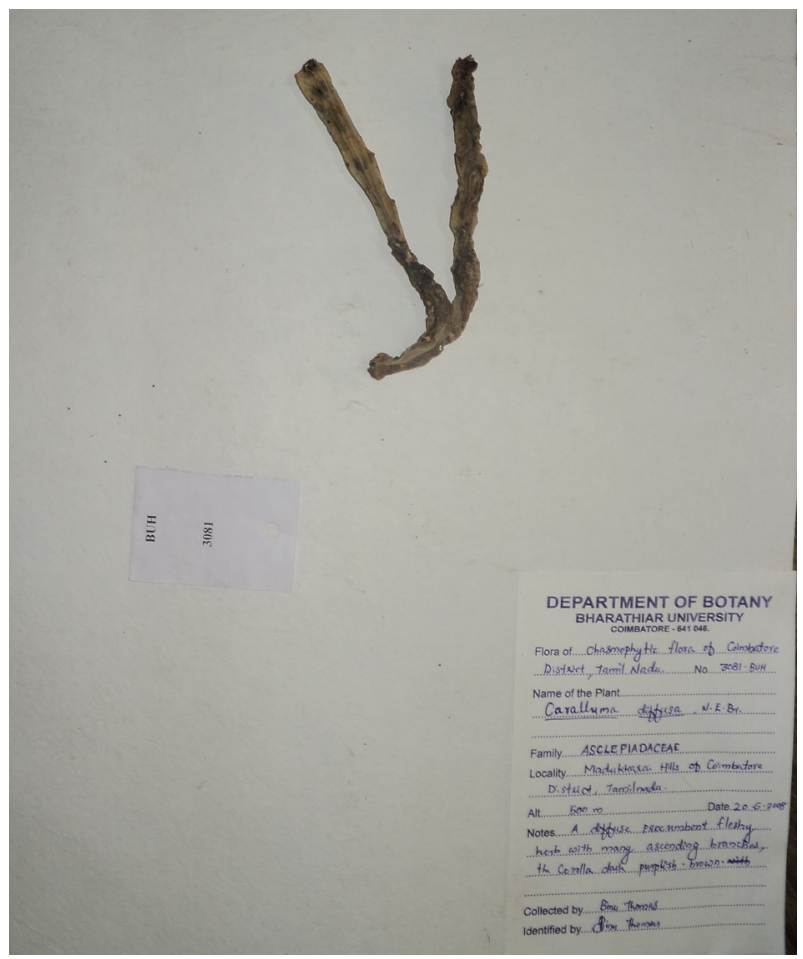

Figure 1. Herbarium of Caralluma diffusa

Environment and Forests, Kolkata, pp. 1451-1510.

Gamble, J.S. \& C.E.C. Fischer (1923). Flora of the Presidency of Madras. Newman and Adlard, London. (Reprint ed. Vol II, 1957. Botanical Survey of India, Calcutta), 862pp.

Gandhi, R (1999). Carallumas of the Indian Subcontinent. The Society of Succulents, New Delhi, 42pp.

Henry, A.N., K. Vivekananthan \& N.C. Nair (1979). Rare and threatened flowering plants of South India. Journal of the Bombay Natural History Society 75(3): 684-697.

Hooker, J.D. (1885). The Flora of British India. Vol. IV: 78. L. Reeve, London, 780pp.

Jagtap, A. \& N.P. Singh (1999). Fascicles of flora of India. Botanical Survey of India, Kolkata. Fascicle 24: 201-202.

Rao, C.K., B.L. Geetha \& G. Suresh (2003). Red Lst of Threatened Vascular Plant Species in India. Compiled from the 1997 IUCN Red List of Threatened Plants, ENVIS, BSI, Ministry of Environment \& Forests, Kolkata, 129pp.

Srinivasan, S.R. (1987). Asclepiadaceae, pp. 80-90. In: Henry, A.N., G.R. Kumari \& V. Chithra (eds.). Flora of Tamil Nadu, Series I: Analysis, Vol. 2: 81. Botanical Survey of India, Coimbatore, 258pp.

Stevens, W.D. (1976). Asclepiadaceae, pp. 437-458. In: Saldanha, C.J. \& D.H. Nicolson (eds). Flora of Hassan District, Karnataka, India. Amerind Publishing Co. Pvt. Ltd., New Delhi, 923pp.

Wight, R. (1850). Icones Plantarum Indiae Orientalis. Vol. IV: t. 1599. J. B. Pharoah, Madras.

Willis, J.C. (1973). A Dictionary of the Flowering Plants and Ferns (Revised by H.K. Airy Shaw). Cambridge University Press, London, 201pp. 